\title{
OPPORTUNITY LOST: THE SUPREME COURT MISSES A HISTORIC CHANCE TO CONSIDER QUESTION OF PUBLIC INTEREST STANDING FOR ANIMAL INTERESTS
}

\section{Peter Sankoff*}

The Supreme Court of Canada recently denied leave to appeal in Reece v. Edmonton (City), a 2-1 decision of the Alberta Court of Appeal, which focused on the right of private parties to seek judicial intervention on behalf of animals. In this article, the author examines the implications of this "lost opportunity" to develop an important area of law relating to public interest standing, explores the important questions that were at stake in the appeal, and suggests why the Supreme Court should have decided otherwise.

La Cour suprême du Canada a récemment rejeté la demande d'autorisation d'appel de l'affaire Reece v. Edmonton (Ville), une décision (2 contre 1) de la Cour d'appel de l'Alberta - qui portait sur le droit de simples individus de demander une intervention judiciaire au nom des animaux. Dans le présent article, l'auteur examine les conséquences de cette [TRADUCTION] « occasion ratée » de développer un important domaine du droit relatif à l'intérêt public, et de traiter les questions sérieuses qui étaient soulevées dans l'appel; il tente d'expliquer pourquoi la Cour suprême aurait dî rendre une décision différente.

No matter how deserving a case you think you might have, the odds are never in your favour when seeking leave to appeal a decision to the Supreme Court of Canada. In a quiet period, parties bringing an application have about a fifteen percent chance of success, while the numbers can drop to less than one in ten in busy years. ' Notwithstanding these odds, and despite losing both at trial and before the Alberta Court of Appeal, the appellants in Reece v. Edmonton (City) ${ }^{2}$ probably felt optimistic in taking their chances and seeking leave. The major issue in the case - whether advocacy groups could receive public interest standing to litigate on behalf of an animal against a decision made by a public body - was

Faculty of Law, University of Alberta.

1 HS Brown \& M Faassen, "Annual Report on Applications for Leave to Appeal to the Supreme Court of Canada: The 2010-2011 Term" (2011) 55 Sup Ct L Rev (2d) 315 at 343 [five year period showing a high of $14.3 \%$ of leave applications granted, with a low of $9.2 \%$ ].

22011 ABCA 238 [Reece]. 
novel, and had the potential to interest the Supreme Court. ${ }^{3}$ More significantly, the decision on appeal had generated a powerful and lengthy dissent from Catherine Fraser, the Chief Justice of Alberta. Given the importance of this last element in the leave process, ${ }^{4}$ there was every reason to believe the case would make it before Canada's highest court and open the door to the justice system for those who wish to defend the interests of animals, a cause some have described provocatively as "the next great social justice movement". It was not to be, however. Instead of becoming the first case to ever reach the Supreme Court on an animal law related issue, ${ }^{6}$ Reece v Edmonton (City) was summarily dismissed, with costs awarded against the applicant. ${ }^{7}$ This brief commentary focuses on the implications of the Supreme Court's decision to deny leave to appeal this novel and interesting decision.

Reece $v$ Edmonton (City) centered on Lucy, a 36-year-old female Asian elephant who lives at the Edmonton Valley Zoo. She is currently the only elephant in the zoo, and advocates have been trying for years to have her moved to a sanctuary in a warmer climate, where she can enjoy the company of other elephants. $^{8}$ The zoo has consistently refused, contending that Lucy receives excellent treatment, and that moving her would be dangerous because of an existing respiratory condition.

Eventually, the stalemate prompted animal advocates to seek a declaration from the Alberta Court of Queen's Bench stating that the City was in violation of provincial regulatory legislation governing the care of animals. ${ }^{9}$ At trial, the claim

3 The case was brought on behalf of three entities: the named party, Tove Reece, and two national animal advocacy organizations: Zoocheck Canada and People for the Ethical Treatment of Animals [PETA].

4 "A dissenting vote in the lower appellate court... catches the eye of the Court; dissents are significantly and positively related to leave applications" [Emphasis added]: R Flemming, Tournament of Appeals: Granting Judicial Review in Canada (Vancouver: University of British Columbia Press, 2004) [detailed study of leave applications showing that dissent in a provincial Court of Appeal one of the most statistically significant factors affecting the leave decision at the Supreme Court].

5 D Weisbrot, "Comment" (2007/08) 91 Reform 2. At the time of making this comment, Weisbrot was the President of the Australian Law Reform Commission. See also E Ellis, "Collaborative Advocacy: Framing the Interests of Animals as a Social Justice Concern" in P Sankoff and S White, eds., Animal Law in Australasia (Sydney: Federation Press, 2009) at 374 [animal advocacy is consistent with action for social justice]; J Anderson, "Protection for the Powerless: Political Economy Lessons for the Animal Welfare Movement" (2011) 4 Stan J of Animal L and Pol'y 3 [charting rise of animal reform movement as important social justice cause].

6 One could argue that Harvard College v Canada (Commissioner of Patents), [2002] 4 SCR 45, which addressed the ability to patent transgenic animals, was the first, but I would contend this was not a true animal law case, as the issues focused more on patent and administrative law than anything concerned with the well-being of animals.

7 Supreme Court of Canada, Judgments in Appeal and Leave Applications, April 26, 2012 (Coram: McLachlin CJ, Rothstein and Moldaver JJ.) online: Lexum <http://scc.lexum.org/en/news_release/2012/12-04-26.3/12-04-26.3.html>.

8 Elephants are very intelligent animals that live in groups and have long-term relationships. As Fraser CJA noted, elephants are "the most social of all mammals, [who] live in complex societies where mothers, daughters, granddaughters, sisters and female cousins retain close relationships for life. And because they are such highly social animals, holding elephants alone, especially females, is injurious to their health". Reece, supra note 2 at para 104.

9 In particular, the Animal Protection Act, RSA 2000, c A-41, s.2, which makes it an offence to permit an animal in one's care to be in distress. 
was struck out both as an abuse of process and on the ground that the claimants lacked standing to bring the application on Lucy's behalf. The decision was then upheld on appeal. According to a majority of the Court of Appeal, the proceedings were an abuse, effectively because it was improper for a private applicant to attempt "to obtain a declaration that a particular respondent was in violation of a penal statute". ${ }^{10}$ Allowing the case to proceed would have frightening consequences, and might encourage "superior courts to review every operational decision made by government".

In a dissenting opinion, Fraser CJA took a very different tack. Taking an expansive view of the right to access justice, she concluded that legal actions should not be dismissed at an early stage except in "plain and obvious cases". 12 Moreover, motions to dismiss should not succeed "where novel, that is arguable, difficult or important, points of law are in dispute", as doing so "would stifle the evolution of the common law". ${ }^{13}$ In her view, the claims raised on behalf of Lucy were novel, but nonetheless justiciable, as at the heart of the case lay a critical question: "Is there no one who can intervene under any circumstances no matter how egregious to protect vulnerable animals from mistreatment by government?" Though she did not answer this question, as it was not before the court, Fraser CJA was of the view that the subject matter was too important to warrant the application being dismissed as an abuse of process. As such, she would have reversed the trial judge's decision to quash the application, and let the matter proceed to trial.

It is impossible to know exactly why the Supreme Court denied leave to appeal, as, in accordance with the Court's practice, reasons were not provided. ${ }^{15}$ Given the starkly differing viewpoints presented by the majority and dissenting opinions at the Alberta Court of Appeal, one has to imagine that the Supreme Court was simply not convinced of the case's "public importance". ${ }^{16}$ This notoriously elusive criterion - the subject of extensive criticism from those who would prefer a clearer threshold in this area ${ }^{17}$ - seems to require that leave seekers raise a fundamental issue of importance to the nation that goes beyond the merits

10 Reece, supra note 2 at para 24.

11 Ibid at para 35.

12 Ibid at para 48

13 Ibid.

$14 \quad$ Ibid at para 162.

15 In $R v$ Hinse, [1995] 4 SCR 597 at para 8, Lamer CJ, explained the practice, stating that "The ability to grant or deny leave represents the sole means by which this Court is able to exert discretionary control over its docket. In order to ensure that this Court enjoys complete flexibility in allocating its scarce judicial resources towards cases of true public importance, as a sound rule of practice, we generally do not convene oral hearings on applications for leave, nor do we produce written reasons for our grants and denials of leave".

16 This is the primary criteria for leave, required by s. 40(1) of the Supreme Court Act, RSC 1985, c. S-26.

17 E White, "By Your Leave: What You Need to Know Before Seeking Leave to Appeal from the Supreme Court of Canada" (2011) 20:7 National 17 [practitioners say there is not enough guidance about what the term means]; S Rodgers, "Getting Heard: Leave to Appeal, Interveners and Procedural Barriers to Social Justice in the Supreme Court of Canada" (2010) 50 Sup Ct L Rev (2d) 1 at 14 [expressing concern about difficulty of assessing what constitutes public importance as access to justice concern; suggesting need for clear guidelines and reasoning]. 
of a particular case. ${ }^{18}$ It helps if the case raises a novel point of law. ${ }^{19}$ Correctness of the lower court's decision is not a critical aspect of the determination, though leave is more likely to be granted where there is reason to be concerned with a legal position taken in the courts below.

On the surface, the facts of Reece $v$ Edmonton (City) do not seem to scream "public importance", as the case did not directly impact the interests of even a single human. ${ }^{20}$ Instead, the application concentrated on the interests of an elephant - a non-human animal, designated by the law as a piece of property owned by the Zoo ${ }^{21}$ - and asked whether important decisions relating to this creature's well-being should be reviewable in the courts. One can to a certain extent understand if the Supreme Court decided that one elephant's care was simply not a matter of public importance warranting its attention.

This result is highly unfortunate, for, like many cases that appear straightforward at first instance, the ramifications of Reece v. Edmonton (City) extend well beyond one particular elephant. In a nutshell, the case asks how obligations to animals under human care should be discharged, whether governments can act in contradiction of their own laws without fear of interference - at least where human interests are unaffected - and, on a meta-level, whether it is possible for legal duties towards animals to have meaning or utility, where the State shows no interest in enforcing them.

In its judgment, a majority of the Alberta Court of Appeal appears to have concluded that the State has full and unreviewable control over the protection of animals, and that individuals seeking to act on behalf of such animals should stay on the sidelines. Its reasons for reaching that conclusion are not unassailable, however. In a recent commentary upon the decision, ${ }^{23}$ Katie Sykes and Vaughan Black were highly critical of the jurisprudence relied upon by the majority as determinative of the case, noting that all of the cases cited involved one private actor attempting to enforce the criminal law against another, and that no Canadian

18 White, ibid at 19.

J Sopinka, "The Supreme Court of Canada" (April 10, 1997), reproduced in H Brown, Supreme Court of Canada Practice 2011 (Carswell: Toronto, 2010) at 489.

20 Unless, of course, one counts the economic interests of the zoo, which likely would have been affected by loss of their only elephant. As the largest land mammal, elephants are known to be serious draws for zoos worldwide: J Sorenson, About Canada: Animal Rights (Halifax :Fernwood, 2010) at 115 [large charismatic animals constitute key attractions for zoos]; C Selley, "Elephants are a Big Problem for Toronto Zoo", National Post (16 February 2011), A10 [citing Toronto Zoo survey that $10.9 \%$ of zoo goers would stop attending zoo if elephants removed].

21 In law, animals are treated as property, characterized as "possessions, chattels and things": L Bisgould, Animal and the Law (Toronto,Irwin: 2011) at 24. The offence of cruelty to animals is contained in Part XI of the Criminal Code, which addresses crimes against property.

22 This is not in any way intended to demean the importance of this case for Lucy, or the efforts of the advocates. Elephants are very special creatures who are thought to suffer horribly when kept without companions, and it is laudable that so many advocacy groups are fighting so hard to have them moved to better places. Indeed, Zoocheck has had success in moving elephants from a number of zoos, including those housed in Toronto. See K Grant, “Toronto Zoo's Elephants Set for Late Summer Move to California", The Globe and Mail, (19 June 2012) online: The Globe and Mail <http://www.theglobeandmail.com/news/toronto/toronto-zoos-elephants-set-for-latesummer-move-to-california/article4352939>. The point being made here is simply that the Supreme Court rarely sees cases that do not directly or indirectly benefit a human plaintiff in a tangible way.

23 K Sykes \& V Black, “Don’t Think About Elephants” (2012) 63 UNBLJ 145 
case had ever explored whether a private citizen could bring the same type of claim against a public actor. The pair was also skeptical of the majority's decision to resort to the abuse of process doctrine without considering in any depth the importance of public access to the courts, and "the availability of judicial review of governmental action that is alleged to be unlawful, or conversely the immunity of such action from judicial oversight". ${ }^{24}$

Shawn Fluker also questioned the Court of Appeal's refusal to let the case go forward. In a blog post on the subject, ${ }^{25}$ he argued that Slatter JA's decision for the majority to quash the claim on procedural grounds reflected a stolid and unnecessary adherence to legal positivism, one that dramatically overstated the potential consequences of allowing the case to proceed. ${ }^{26}$ As a result, a valuable chance to explore the merits of the contesting groups' claims on behalf of Lucy within a clear factual context was lost. Fluker also critiqued the majority for neglecting important aspects of the case in reaching its decision: first, the fact that the applicants were actually attempting to advance the interests of a sentient being who could not come before the court herself; ${ }^{27}$ and second, that the applicants were not randomly attacking a private decision but were instead effectively critiquing the government's failure to hold itself to account. ${ }^{28}$

Looked at in light of these criticisms, one can see that Reece v. Edmonton (City) in fact raised a number of interesting legal questions directly connected to the ability of citizens to access the justice system on behalf of animals who may be enduring a great deal of harm and suffering. ${ }^{29}$ Indirectly, the case also asks whether an entity like the Edmonton Zoo, with its vested economic interest in keeping Lucy, ${ }^{30}$ should be able to make what amounts to a virtually unreviewable decision about an animal's care.

Sadly, the decision of the majority of the Alberta Court of Appeal to stop the process before considering its merits is all too familiar, as challenges to the status quo raised on behalf of animals almost always run into this sort of jurisprudential

$24 \quad$ Ibid at 153.

25 S Fluker, "The Elephant in the Courtroom", (1 September 2011) online: Ablawg

<http://ablawg.ca/20-11/09/01/the-elephant-in-the-courtroom/\#more-1136>.

26 Fluker took particular issue with Slatter JA's contention that the application was "asking the Court to operate the zoo... [or] review every decision of government".

27 As noted by Sykes \& Black, supra note 23 at 154, "it is unlikely that [a claim of unsuitability for judicial review] would be made if the interests of human beings, rather than animals, were at stake".

28 Or, as Fluker puts it, "it is a mockery of the law to expect the Attorney General to prosecute the executive in this case". Fluker, supra note 25 . Fraser CJA similarly noted, that the majority ignored the fact that there were no alternatives to the action, in that "[a] reasonable and effective alternative to a proceeding holding the executive branch to account cannot logically be a proceeding which can only occur with the effective consent of the executive branch". Reece, supra note 2 at para 191 ,

29 To be clear, it was at no stage established that Lucy was suffering, though the applicants put up an impressive array of facts to prove this contention. Because this was a summary application to dismiss, the facts were effectively accepted as tendered, with the application being considered strictly on legal grounds. Reece, ibid at para 15 .

30 Again, this is not intended to disparage the zoo, which may well have had the best of intentions towards Lucy, but one cannot ignore the potential for a conflict of interest here. Zoos are in the profit-making business. Their animals are, in effect, their "merchandise", and it is conceivable and there are many examples of this occurring - that zoos will make decisions in their own best interest, and not those of the animal. 
trap. Simply put, the law as it currently exists is just not designed to allow legal review of decisions made regarding animals, primarily because these animals are the objects of rights-holders, rather than rights-holders themselves. Animals lack the legal personhood required to pursue their own claims, and the courts have been parsimonious about permitting sympathetic human claimants to take legal action on the animals' behalf. ${ }^{32}$ Most challenges designed to help animals are cut off at the knees, either on the ground that the applicants lack standing to continue, or, as in this case, as abuses of the court's process. For this reason, the courts rarely consider the substantive issues in question, to wit: (1) should concerned individuals ever be able to act on behalf of animal interests, especially where those interests are contrary to those held by property owners, and (2) when can individuals challenge a government's refusal to protect animal interests in compliance with a public statute designed to accomplish that feat?

Whatever one thinks of the ultimate merits of these questions, or of the criticisms leveled at the majority decision in Reece v. Edmonton (City), it is difficult to see how they can be summarily dismissed when they were convincing enough to prompt the Chief Justice of the Alberta Court of Appeal to write a lengthy judgment exploring the reaches of the abuse of process doctrine in civil cases involving public bodies and the ability of the justice system to extend notions of justice to non-human animals, both matters that Canadian courts have never before considered in any detail. Notwithstanding Fraser CJA's revolutionary opinion, ${ }^{33}$ this remains the most difficult obstacle faced by animal advocates trying to advance their cases: getting judges to accept that legal issues involving animals are challenging and worthy of their attention. Despite achieving some progress at a societal level, ${ }^{34}$ the pervasive view of "it's only an animal" remains hard to shake in the courtroom, and it is difficult to imagine this factor did not have some impact on the Supreme Court's decision.

31 M Bridge, ed, Benjamin's Sale of Goods, $8^{\text {th }}$ ed (London: Sweet \& Maxwell, 2010) at 76 [all animals are capable of being owned absolutely]. As J Waldron, The Right to Private Property (Oxford: Clarendon Press, 1988) at 27 has noted, "property cannot have rights or duties or be bound by or recognize rules".

32 Obtaining standing to litigate on behalf of animals is generally regarded as one of the most significant challenges for animal advocacy groups. See C Sunstein, "Standing for Animals (with notes on Animal Rights)" (2000) 47 UCLA L Rev 1333; M Hogan, "Standing for Nonhuman Animals: Developing a Guardianship Model from the Dissents in Sierra Club v. Morton" (2007) $95 \mathrm{Cal}$ L Rev 513.

33 Sykes \& Black, supra note 23 at 147, noted their surprise at the wide-ranging discussion in the opinion, noting that while animal law issues are gaining prominence in scholarly and public debate, "to see them addressed at all in an appellate court decision is surprising, and... to see [the issues] given such thorough and sincere consideration is little short of astonishing".

There are numerous recent examples of public outrage arising over animal care. The recent uproar over the care of captive dolphins at MarineLand, in Ontario, following an expose in the Toronto Star, is one of the more prominent: see L Diebel, "Marineland animals suffering, former staffers say", Toronto Star (15 August 2012) online The Toronto Star <http://www.thestar.com/news/cana-da/article/1241961--marineland-animals-suffering-former-staffers-say>. Progress is also being made in the classroom, as courses on animal law are becoming more prevalent worldwide. See P Sankoff, "Charting the Growth of Animal Law in Education" (2008) J Animal L 105; J Tischler, "A Brief History of Animal Law: Part II (1985-2011) (2012) 5 Stan J Animal L \& Pol'y 27.

35 Sykes \& Black, supra note 23 at 154, suggest this may be the case, noting that "[p]erhaps Slatter J.A. means that the issue is unsuitable for the courts because asserting the interests of animals is not a suitable thing to do in court". 
The Supreme Court's decision to refuse leave stands in stark contrast to the recent trend in foreign jurisdictions. After decades of ducking these sorts of questions, courts around the world are cottoning on to the fact that animal issues raise matters of societal importance that are in fact justiciable. ${ }^{36}$ A wonderful example of this is the High Court of Israel decision from 2003, Noah (Israeli Federation of Animal Protection Organizations) v. Minister of Agriculture, perhaps the most famous animal law case ever decided anywhere. The decision is of course important for its substantive result, which shut down the foie gras industry in Israel and demanded that the government of Israel comply with its own animal welfare legislation. ${ }^{38}$ But almost as important was the Court's attitude to the issues being considered, and the seriousness and depth with which these were treated. Consider this excerpt from the majority judgment, written by Judge Strasberg-Cohen:

The issue is complex, the problem is complicated and the decision is not simple. It requires the creation of a multi-factorial system of balances, taking into account "the essence and importance of the conflicting principles, our perception of their relative superiority and the amount of protection we wish to grant to each principle or interest"... On the one hand lies the interest of protecting animals and their welfare. On the other hand lies the right of a person to use animals for his livelihood and welfare.

Judge Strasberg-Cohen was correct. Questions involving the best way to reconcile the interest of animals and competing human needs and desires are complex, and the answers not always apparent. In her lengthy, carefully considered opinion in Reece v. Edmonton (City), Fraser CJA demonstrated that the judicial creativity needed to develop the law in this area is possible, and, moreover, that there are good reasons to think "outside of the box" where non-human animal interests are at stake. As she noted:

Some may consider this appeal and the claims on behalf of Lucy inconsequential, perhaps even frivolous. They would be wrong. Lucy's case raises serious issues not only about how society treats sentient animals - those capable of feeling pain and thereby suffering at human hands - but also about the right of

36 See for e.g., "The Oxen Festival Case", where Brazil's Supreme Court banned the popular oxen festival, on the grounds that it caused cruelty to the animals, described by L Clayton, "Overview of Brazil's Legal Structure for Animal Issues", (2011) online: Animal Legal \& Historical Center <http://www.animallaw.info/topics/tabbed_nonus/spbrazil.htm>. See also State of Gujarat $v$. Mirzapur Moti Kureshi Kassab Jamat, Appeal 4937-4940 of 1998, 25 October 2005 (Supreme Court of India) [bans on slaughter of cows].

37 9232/01, August 11, 2003, Supreme Court of Israel, translation available online: Animal Legal \& Historical Center <http://www.animallaw.info/nonus/cases/cas_pdf/Israel2003case.pdf> [Noah].

38 Without question, the legal context and procedural rules in Israel that allowed this claim to be brought are quite different, and the applicants had a much easier time getting the case to court in the first place. Nonetheless, the basics of the claim - a request for the judiciary to compel action 39 by a government body that was refusing to act - are not dissimilar from Reece v. Edmonton (City).

39 Noah, supra note 37 at para 1. 
the people in a democracy to ensure that the government itself is not above the law.

As this excerpt from Fraser CJA's opinion implies, the biggest hurdle to overcome in asking courts to reconsider established doctrine and take a bold new approach to an area of human interaction that has never previously been the subject of judicial supervision is the reflexive tendency towards dismissal, derision and scorn. In declining leave to appeal, the Supreme Court effectively concluded that issues surrounding animal care were not important enough at this juncture to warrant further discussion. This maintenance of the status quo is disappointing, ${ }^{41}$ as, owing to the aforementioned procedural hurdles and costs of litigation, cases of this nature are not being mounted regularly. Furthermore, those that do come forward are unlikely to receive a platform as rich as the dissenting opinion provided by Fraser CJA in Reece. Sadly, the refusal to grant leave on this occasion compounded by the Court's dubious decision to add insult to injury and order costs against the applicants, ${ }^{42}$ public interest litigants with limited resources ensures that it may well be a long time before the questions at stake in Reece $v$ Edmonton (City) achieve the national platform they so richly deserve.

$40 \quad$ Reece, supra note 2 at para 39.

41 For a similar argument in regard to environmental claims, see H McLeod-Kilmurray, "Does Preserving the Environment Advance or Conflict with Social Justice and Human Rights" (2010) 50 SCLR (2d) 465 at 497, who notes that "if litigants perceive a trend of refusing leave in environmental cases, this may dissuade environmental litigants from even seeking to litigate, and this in itself is a serious access to justice - and to that extent a social justice - problem".

42 Though it is hardly uncommon for the Supreme Court to award costs against the losing party on an application seeking leave to appeal, the decision is entirely discretionary. A quick perusal of the Court's leave decisions reveals that a substantial number of civil claims are, in fact, dismissed without costs against the unsuccessful applicant. The Court's decision to impose costs in this case goes against a growing line of argument suggesting that public interest litigants with meritorious claims should not be the subject of such costs orders, even when their claim is unsuccessful. See C Tollefson, "Costs in Public Interest Litigation Revisited" (2009) 39 Advocates' Q 197. The award seems to imply a perceived lack of merit in the decision to seek leave to appeal, which is simply astonishing given the presence of Fraser CJA's dissenting opinion. 